\title{
Environmentally sustainable agriculture in Poland - economic assessment
}

\author{
Wioletta Wrzaszcz ${ }^{1}$, PhD; Konrad Prandecki ${ }^{1}, \mathrm{PhD}$
}

\begin{abstract}
Agriculture is particularly linked with natural environment, due to the necessity of natural resources exploitation in the process of agricultural production. Intensive agricultural activity can cause exhaustion of the natural resources and some reduction in agricultural productivity. This interrelation substantiates promoting different forms of sustainable agriculture, that ensures, on the one hand, the volume and profitability of agricultural production, on the other hand, respect for the natural environment.

The paper objective is the economic assessment of different forms of environmentally sustainable agriculture in Poland.

There were analysed a few groups of farms with a different range of agrienvironmental practices, such as: a) industrial - specialized in cereal intensive production; b) sustainable - with balanced plant and animal production; c) ecological - organized according to legal rules, d) norfolk - with balanced plant production; e) agrienvironmental - taking part in rural development program. Economic efficiency was calculated on the basis of productive and economic indicators, i.e.: total farm output, farm gross value added, family farm income. The analysis was based on Farm Accountancy Data Network 2012, that covered 11000 holdings - the representative sample for commodity farms in Poland (750 000).
\end{abstract}

Keywords: productivity, agriculture, externalities, environment

\section{Introduction}

Agriculture, because of its specific nature, is particularly connected with the natural environment. This means that to taking care of the quality of nature and natural resources is not only a civilizational requirement, but also a prerequisite for the operation of agricultural production. Each agricultural activity requires above all the access to water, an appropriate climate and soil quality (Rapidel et al., 2011). In addition, the interactions between agriculture and the environment are determined, among other things, by the level of biodiversity, the condition of the landscape and the volume of emissions.

So far, the dominant industrial agriculture has not attached great importance to the environment, driven primarily by the income criterion (Woś \& Zegar, 2002). Ensuring the sustainability of agricultural production necessitates the use of the concept of sustainable development, which covers the profitability of production while keeping the environment in a good condition. Implementation of sustainable agriculture involves the necessity to carry out a detailed analysis of production and economic aspects. This analysis makes it possible to comprehensively assess the economic efficiency of a farm, including the productivity and profitability of the utilised factors of production. Environmental issues should be included in both of these components. The level of productivity of farms is determined mainly by the way of using of natural resources. On the other hand, the social value of environmental resources is directly reflected in the cash flow - the fees, taxes and subsidies - which takes place between a farmer and the state. 
An economic and production analysis is conducted mostly on the basis of the theory of mainstream economics. Such an approach makes it possible to evaluate the implementation of objectives from the point of view of the economic optimum. Its disadvantage consists in ignoring most of the environmental and social factors because it is not possible to determine their market value. In a situation when the negative pressure of a human being on the environment increases, such an approach can be hardly accepted.

Environmental factors (inputs and outputs) should be included in the economic and production analysis when calculating the productivity. There are two basic ways to achieve this goal. Firstly, a new productivity indicator based on the internalisation of externalities may be formed ${ }^{1}$. Secondly, the assessment may cover specific agricultural practices that are compliant (more or less) with the sustainable farming criteria.

Another way to assess the productivity of agriculture in the context of sustainable development is to examine the relevant agricultural practices (Prandecki et al., 2014). It does not require meticulous measurement of individual externalities and their interrelationships. The key element of this approach is to conduct an accurate and need-based identification of the criteria for the breakdown of farms (Wrzaszcz, 2014). They should be chosen so as to reflect the priorities of sustainable development in the best possible way. These methods are commonly used, which is their advantage when making such comparisons, e.g. international ones.

The aim of this article is to present an economic and production analysis for selected forms of sustainable agriculture. The identification of several forms of farming makes it possible to determine the impact of various environmentally friendly agricultural practices on the economic and production analysis.

\section{Research object and method}

The analysis considered 10,600 farms covered by the Farm Accountancy Data Network in Poland in 2012. The study lists the forms of sustainable agriculture ${ }^{2}$ and their contrast group of specialised cereal farms. Such farms were analysed in terms of the production potential and the economic and production results.

Environmental friendliness of farms is assured to a different degree by various forms of farming. The study highlights selected four groups of farms that featured environmentally friendly agricultural activity. A detailed analysis covered the following farms:

Organic farms (ECO) - farms with a certificate granted by an approved certification body and farms during the process of transition to that system of agricultural production. The guiding principle in the organic system is to cultivate plants in compliance with the standards of the Good agrienvironmental practices with due attention to the phytosanitary condition of plants and soil protection. Such farms are obliged to keep an area of permanent grasslands and landscape elements not used for agricultural purposes ${ }^{3}$.

Agri-environmental farms (AGRIENV) - the farms that participate in the agri-environmental programme included in the Rural Development Programme 2007-20134. The goal of the programme is

1 The attempts of studies in accordance with this method have already been taken quite often (Gollop \& Swinand, 1998; Melfou et al., 2007). The main drawback of this method is the necessity to assess the value of externalities. There are problems with their choice (usually only the selected effects are included in the account), data sources and ambiguous value assessment methods (Byerlee \& Murgai, 2001).

2 Forms of sustainable farming have also been examined, e.g. in publications: (Prandecki et al. 2014; Wrzaszcz \& Zegar, 2014).

3 The list of legal regulations in the field of organic farming system can be found on the website of the Ministry of Agriculture and Rural Development: http://www.minrol.gov.pl.

4 Ibidem. 
to improve the quality of the natural environment, in particular to preserve biodiversity within rural areas; to promote sustainable farming; to appropriately use of soil and water conservation; to protect endangered local livestock breeds and plant varieties.

Norfolk farms (NORF) - such farms have a diversified field crop structure, which has a positive impact on the fertility of soil $(50 \%$ cereals, $25 \%$ grain legumes and fodder plants, $25 \%$ root crops). Such a structure guarantees the cultivation of cereal crops after good previous crops i.e. after non-cereal plants. The use of mixed crop rotations involving legumes and catch crops for green manure is necessary to maintain a sustainable soil fertility.

Sustainable farms (SUSTAIN) - such farms were characterised by selected criteria of environmental friendliness of agricultural production. Agricultural production in such farms has not abused natural resources, which was a result of mixed crop rotations and their rational fertilization adapted to soil fertility with the macronutrients. The following criteria have been included as environmental sustainability criteria (Wrzaszcz, 2014):

the share of cereals in crop structure on arable land - determines the correctness of crop rotation and the degree of agrocenose biodiversity; share of cereals in crop structure should not exceed $2 / 3$ of the area,

the number of plant groups cultivated on arable land - indicates the possibilities of crop selection and rotation, which increases the guarantee of limiting the development of pest populations, reducing weeds and losses; at least three plant groups should be cultivated,

the index of vegetation cover on arable land in winter - is a synthetic indicator for the assessment of land resources, the balance of ecosystems and the degree of implementation of sustainable production system in agriculture; vegetation cover on arable land in winter should be at least $1 / 3$ of the area,

stocking density on agricultural land - provides information about the level of intensity, and also indicates the scale of the environmental impact of natural fertilizers; stocking density on agricultural land should not exceed $2 \mathrm{LU} / \mathrm{ha}$.

The opposite group for the above-mentioned forms of sustainable agriculture was formed by cereal farms (INTENS) ${ }^{5}$. Narrow specialisation of crop production in such farms (monoculture of crops or crop production with low species diversity) shows that such agricultural practices are far from the ones included in the principles of sustainable development of agriculture. Therefore, they can be regarded as unsustainable. Such an approach makes it possible to indicate differences in productivity between industrial and sustainable agriculture.

For the groups of farms listed above, there was presented their number and the basic characteristics of the production potential measured by the following indicators: the area of agricultural land (ha), the labour input $\left(\mathrm{AWU}^{6}\right)$, the stocking density $\left(\mathrm{LU}^{7}\right)$, the value of assets, the standard output value ${ }^{8}$ and the standard gross margin $\left(\mathrm{ESU}^{9}\right)$. Subsequently, the economic

${ }^{5}$ Farm classification rules for particular types of farming are detailed in publications (Goraj et al.,

61 AWU (Annual Work Unit) is equivalent to full-time own and paid labour, i.e. 2,120 hours of work a year. On the other hand, 1 FWU (Family Work Unit) is the equivalent of a full-time labour of a farming family member.

$71 \mathrm{LU}$ - Livestock Unit is a conventional unit of farm animals with a mass of $500 \mathrm{~kg}$.

8 Standard output is the mean of 5 years of the value of production corresponding to the average situation in the region. Total standard production of farms is the sum of the values obtained for each agricultural activity on the farm by multiplying the coefficients of the standard output for a given activity and the number of hectares or number of animals; see (Goraj et al., 2012). It is an economic category that allows for comparing the volume of production, while offsetting the impact of price fluctuations in regional and temporal terms.

${ }^{9}$ Sum of standard gross margins - the difference between output and specific (direct) costs of all activities occurring on the farm - indicates the economic size of the farm, otherwise the productive potential 
efficiency of farms was assessed by means of the following indicators:

Land Productivity: Total Output/Agricultural Land; Gross Farm Income/Agricultural Land.

Labour Productivity: Total Output/Annual Work Unit; Gross Farm Income/Annual Work Unit.

Land Profitability: Family Farm Income/Agricultural Land.

Labour Profitability: Family Farm Income/Family Work Unit.

The Total Output of a farm represents the basic economic and production category that indicates the economic result of farming. It is the outcome of the sum of the value of crop and livestock production and other activities.

Gross Farm Income is the result of difference of Total Output and the Total Intermediate Consumption (Total specific costs - including inputs produced on the holding - and overheads arising from production in the accounting year), adjusted for the outcome of the balance of current subsidies and taxes. This value indirectly makes it possible to verify the impact of farming efficiency measured by the level of costs and subsidies.

Family Farm Income is the primary economic goal of farmer's activity and it is an essential determinant of a farmer family living standard, and hence it may be an important indicator of farm efficiency in agriculture.

\section{Production potential}

The study covered 10,589 farms with FADN accounting (Table 1). The largest group among all the analysed forms of sustainable agriculture was formed by agri-environmental farms $(23 \%)$, followed by sustainable ones $(22 \%)$ and by the norfolk ones $(15 \%)$, whereas organic farms were the smallest fraction (4\%). Highly specialised cereal farms represented $13 \%$ of the surveyed entities.

The average area of the examined farms amounted to 37 ha, just like the size of an organic and norfolk farm. In this respect, agri-environmental and sustainable farms (with a difference of ca. $20 \%$ compared to the average) and cereal farms (over two times larger) strongly distinguished themselves in a positive way. The differences resulted from the area structure of analysed groups of the farms. Every second cereal farm had an area of at least 50 ha, whereas only every fourth/fifth farm with sustainable agricultural production had such an area. Guided by the level of labour inputs, it can be concluded that most of the examined forms of sustainable agriculture (excluding the norfolk ones) and cereal farms were characterised by relatively better organisation of work.

The average size of a herd of animals in the farm in question amounted to $27 \mathrm{LU}$. In comparison to that, only the organic and cereal farms significantly deviated from the average 14 and $2 \mathrm{LU}$ respectively). While in the latter case, it is understandable because of the nature of production of specialised cereal farms, such a result is not justified for organic farms. The main idea of organic production is to keep a closed circuit of nutrients within a farm, which should lead to mixed agricultural production. The presented data confirm the discrepancy between theory and practice in agriculture ${ }^{10}$. The differences in the area of the selected groups of farms and in the livestock

of the farm. 1 ESU is equivalent to EUR 1,200. The standard gross margin is the average gross margin by region. Standard gross margin on a particular crop or animal is a standard (average of three years in a particular region) value of production obtained from one hectare or from one animal minus the standard direct costs necessary for production.

${ }^{10}$ Studies have demonstrated that there is a growing problem involving not only limiting the scale of animal production on organic farms, but even giving up such production; see (Nachtman, 2014; Wrzaszcz \& Zegar, 2014). 
population were reflected in the total value of their assets. Organic farms were characterised by the lowest value of the assets (ca. $1 / 4$ as compared to an average farm) in contrast to cereal farms (it was higher by ca. $1 / 2$ as compared to the average).

The standard gross margin made it possible to synthetically evaluate the economic potential of the identified groups of farms. Only organic farms differ in this respect from the average - the result was lower by $38 \%$. On the other hand, cereal farms - despite their area being twice as large as the average - are characterised by the same production potential. This result is a proof of the importance of animal production and diverse crop production for the value of the standard gross margin. Multifunctionality of agricultural production and diversified crop structure contributes not only to the assurance of environmental benefits, but also tangible economic benefits.

Table 1. Production potential of analysed farms`groups (average per farm)

\begin{tabular}{|l|l|l|l|l|l|l|l|}
\hline \multirow{2}{*}{ No. } & \multirow{2}{*}{ Specification } & \multirow{2}{*}{ TOTAL } & \multirow{2}{*}{ INTENS } & \multicolumn{3}{|l|}{ Forms of sustainable agriculture } \\
\cline { 5 - 8 } & & & & ECO & AGRIENV & NORF & SUSTAIN \\
\hline 1 & Number of farms & 10589 & 1389 & 422 & 2487 & 1540 & 2309 \\
2 & Agricultural land (ha) & 36,8 & 74,7 & 37,4 & 45,3 & 36,2 & 44,4 \\
3 & Labour input (AWU) & 2,01 & 1,70 & 1,89 & 1,96 & 2,06 & 2,05 \\
4 & Livestock units (LU) & 27,3 & 2,1 & 14,4 & 27,5 & 31,2 & 25,9 \\
5 & Total assets (thousand EUR) & 294,3 & 434,9 & 214,5 & 326,3 & 299,6 & 353,7 \\
6 & Standard gross margin (ESU) & 21,7 & 21,6 & 13,5 & 23,0 & 21,5 & 23,4 \\
\hline
\end{tabular}

Source: Prepared on the basis of FADN 2012 data.

\section{Economic and production results}

The basic economic and production category is the total output value, which consists of the value of crop and livestock production and other activities ${ }^{11}$. The value of agricultural production is predominantly determined by the total output value (it represents 97-99\% depending on the form of sustainable agriculture). The relatively largest importance of the other kind of production can be seen in organic farms (3\%), which results from a slightly different organisation of such farms. Frequently, agricultural production on organic farms is supplemented for instance with agri-tourism based on the assets of a farm.

The total output value with reference to the utilised agricultural area is one of the key indicators to measure productivity. Land productivity on an average individual farm amounted to EUR 1,691/ha (Fig. 1a). Compared to that, the agri-environmental, sustainable and norfolk farms achieved lower results (lower by 17\%,11\% and 9\% respectively), but organic farms deviated from the average in particular - their result was lower by $58 \%$. The presented figures confirm the lower land productivity on farms that provide services for the natural environment - of course if we measure it in static terms. It is very likely that in the long term and with a full account of the costs and benefits - of the externalities - these relations would be the opposite. It should be pointed out that farms with a simplified crop structure, with intense production and the ones that exploit the surrounding natural resources do not generate impressive production results and, what is more, they are far from the average (the total output value was lower by $36 \%$ compared to the average). The above-mentioned results suggest that a simplified crop production results not only in negative environmental effects, but it is even not justified in purely economic terms. On the

11 It includes mainly: rent for leased land, forest products, provision of services, equipment rental, income from agri-tourism. 
other hand, most farms operating in accordance with the laws of nature provide a sufficient volume of agricultural production. The differences between the studied farms would be probably more distinct in a full economic account including the value of externalities.

Another indicator to measure the productivity is the total output value relative to labour inputs, i.e. labour productivity. Agri-environmental and sustainable farms achieved comparable results in this respect as the average entities while organic and norfolk farms - just like in terms of land productivity - had significantly lower results (with the difference amounting to $54 \%$ and $13 \%$ respectively). Cereal farms, the results of which exceeded the average by as much as $54 \%$, represented the contrast group in this respect. Cereal farms with intensive production distinguish themselves with relatively low labour intensity of production, which is a result of both a simplified crop production, giving up the absorbing livestock production and an efficient use of their own labour resources.

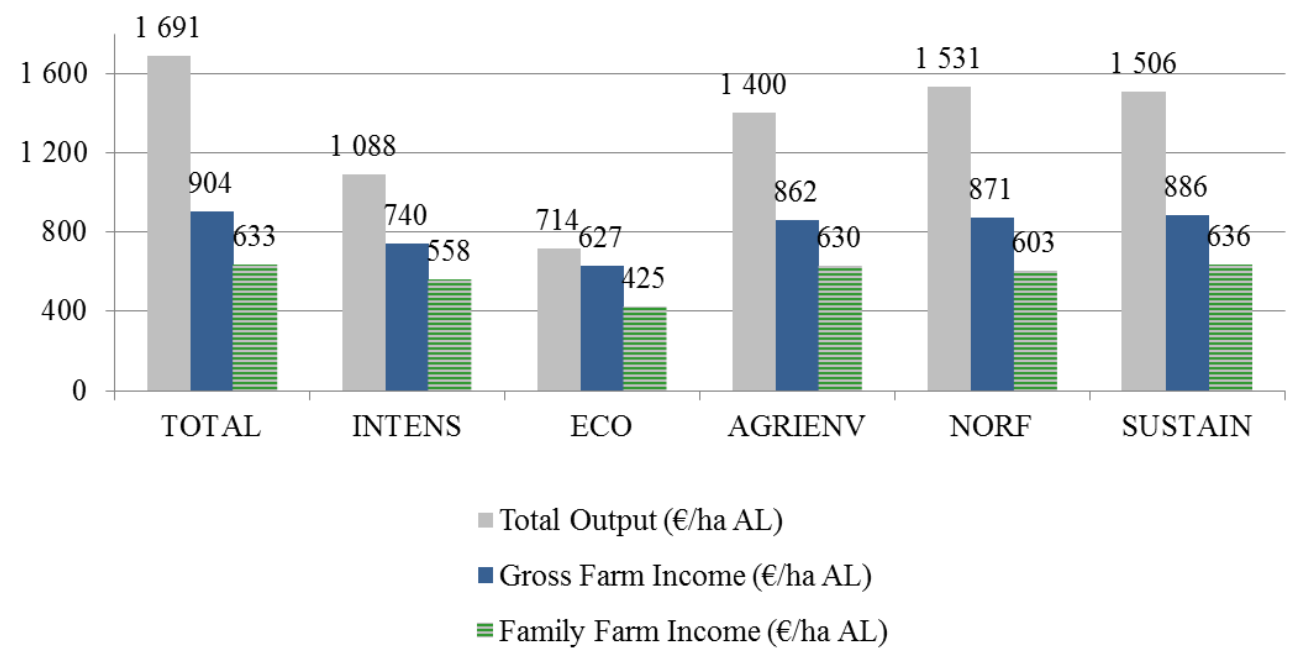

Figure 1. Productivity and profitability of land in analysed farms' groups.

Source: Prepared on the basis of FADN 2012 data. 


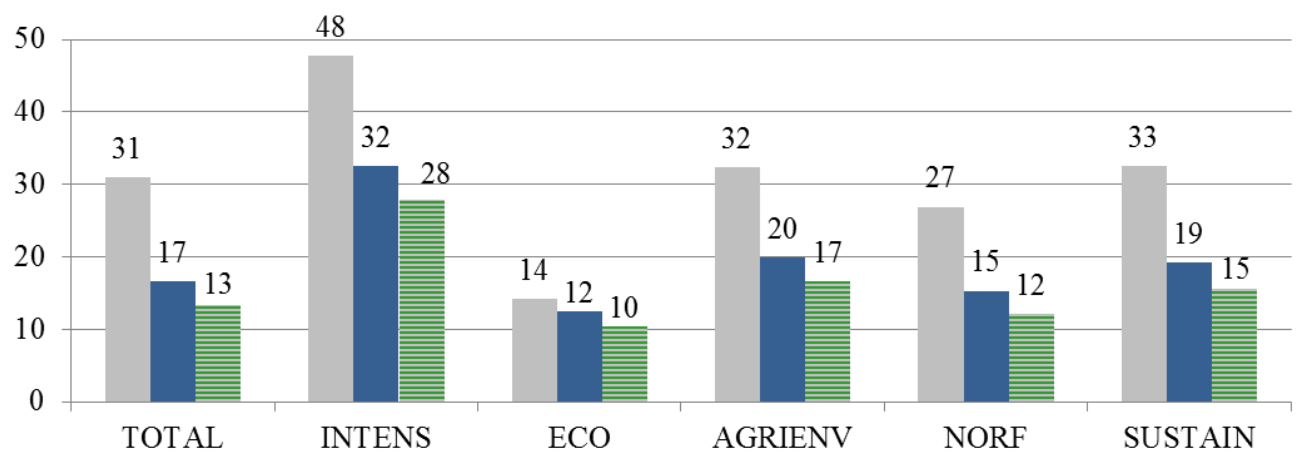

- Total Output (thousand $€ /$ AWU)

- Gross Farm Income (thousand $€ / A W U)$

$\equiv$ Family Farm Income (thousand $€ / F W U$ )

Figure 2. Productivity and profitability of labour in analysed farms' groups.

Source: Prepared on the basis of FADN 2012 data.

Total specific costs and farming overheads associated with the operation of a farm are expressed in the form of total intermediate consumption. Such costs on an average farm amounted to EUR 1,003/ha (Table 2). In this respect, cereal farms and the ones that provide services for the natural environment were characterised by a lower production intensity. Organic farms distinguished themselves in this respect in particular, which results from the specifics of this production system, which is based on small and justified use of external means of agricultural production.

The Common Agricultural Policy instruments that are currently under implementation determine the opportunities for obtaining financial support by agricultural producers through environmental restrictions and for compensating the services provided for the environment. These determinants have the form of regulations, such as cross-compliance, that are linked to direct payments, refer to diversification of that type of payments depending on the chosen plant species and animals production activities and include the activities for the sustainable development in the form of e.g. environmental programmes ${ }^{12}$. The implementation of these measures by farmers is confirmed by the level of subsidies they receive. An account drawn up in accordance with the FADN methodology distinguishes the category of the balance of subsidies and taxes connected with current productive activity. The category indicates the direction of the transfer of funds to a farm when it adopts a positive value. For all the forms of sustainable agriculture in question, this category was significantly higher than the average result for the population of the analysed farms. These differences indicate that the measures taken for the environment are compensated by the state with funds, however there is still a question whether they are sufficient.

\footnotetext{
12 www.minrol.gov.pl.
} 
Table 2. Selected categories of economic calculation for analysed farms` groups (EUR/ha)

\begin{tabular}{|c|c|c|c|c|c|c|c|}
\hline $\begin{array}{l}\mathbf{N} \\
\mathbf{o .}\end{array}$ & Specification & $\begin{array}{l}\text { Tot } \\
\text { al }\end{array}$ & $\begin{array}{l}\text { INTE } \\
\text { NS }\end{array}$ & $\begin{array}{l}\text { EC } \\
\text { O }\end{array}$ & $\begin{array}{l}\text { AGRIE } \\
\text { NV }\end{array}$ & $\begin{array}{l}\text { NOR } \\
\text { F }\end{array}$ & $\begin{array}{l}\text { SUSTAI } \\
\mathbf{N}\end{array}$ \\
\hline 1 & Total intermediate consumption & $\begin{array}{ll}1 \\
003\end{array}$ & 555 & 407 & 845 & 893 & 842 \\
\hline 2 & Balance of current subsidies \& taxes & 216 & 207 & 319 & 306 & 233 & 222 \\
\hline 3 & Gross Farm Income & 904 & 740 & 626 & 862 & 871 & 886 \\
\hline 4 & Depreciation & 205 & 133 & 140 & 179 & 213 & 192 \\
\hline 5 & Farm Net Value Added [3-4] & 699 & 607 & 486 & 683 & 659 & 694 \\
\hline 6 & Total external factors $[7+8+9]$ & 78 & 59 & 70 & 69 & 76 & 74 \\
\hline 7 & $\begin{array}{l}\text { Balance of subsidies \& taxes } \\
\text { investments }\end{array}$ & -40 & -32 & -19 & -38 & -44 & -44 \\
\hline
\end{tabular}

Source: Prepared on the basis of FADN 2012 data.

Gross Farm Income is a category that reflects the increase in value of goods produced in a given agricultural holding with the involvement of all three factors of production. Furthermore, it reflects the impact of the agricultural policy on the economic situation of farms by means of the system of subsidies and taxes (Goraj, 2009). Gross Farm Income on an average farm amounted to EUR 904/ha. The conducted static analysis indicates that the forms of sustainable agriculture are imcomparatively lower than the other farms in terms of produced volume of agricultural production, and policy instruments compensate for such differences only to a certain degree. Despite a high share of the balance value of current subsidies and taxes in the Gross Farm Income, in particular in the case of organic and agri-environmental farms, their results are still below average (51\% and 36\% respectively). The result of the Gross Farm Income on farms oriented to cereal monoculture also differs from the average (the result is lower by $18 \%$ ). It indicates the lack of justification for the simplification and narrow specialisation of agricultural production, both in terms of microeconomic rationality (oriented to economic benefits) and social rationality (oriented around concerns for public goods).

Net value added adjusted for the cost of total external factors and the balance of subsidies and taxes on investments indicates the level of farm income (Bocian \& Malanowska, 2014). The cost of total external factors includes the salaries of employees (including social insurance of salaried employees), the rents associated with the lease of land and buildings and the interest and fees associated with the loans contracted for the purchase of land, buildings, machinery, equipment, livestock and materials. The volume of income illustrates the level of compensation for the involvement of their own factors of production in the farm's operations and for the risk taken by the farm manager in a given financial year.

Land and labour profitability in family farms are illustrated in Fig. 1 and 2 . On average, the use of 1 ha of utilised agricultural area made it possible to generate income amounting to EUR $633 /$ ha. A comparable result was also featured in agri-environmental, norfolk and sustainable farms. It is important information because it is proof of similar profitability of environmentally friendly agricultural production. It should be pointed out that, despite lower land productivity of the analysed forms of sustainable agriculture, the support system in the form of subsidies (mainly for current activity) and - actually first of all - a more efficient organisation of a farm, reflected in the level and structure of costs associated with the operation of a farm, made it possible to provide results comparable to average farms. Only organic farms still had a significant economic distance to other examined fractions (EUR 425/ha). The presented results may be a sign of insufficient legal and financial protection of that production system because they compensate for a small part of the low profitability of the factors of production. For comparison, farms that generate negative externalities - in this analysis, they are cereal farms - also can not be considered a lucrative way of farming (their result amounted to EUR 558/ha).

A slightly different picture emerges when analysing the labour profitability of the selected 
groups of farms. One full-time worker for own labour on an average farm achieved a result of EUR 13,000/FWU. A comparable labour profitability was characterised by norfolk farms while the result for agri-environmental and sustainable farms was even more favourable (higher by $24 \%$ and $16 \%$ respectively compared to the average). The above results and relationships between them are considered promising, considering their further development. Unfortunately, organic farms still take the last position (EUR 10,000/FWU, the negative difference amounting to 23\% compared to the average), which strengthens previous observations on this system of farming in agriculture. On the other hand, the very high profitability of production for cereal farms (EUR 28,000/FWU, being two times higher than the average) gives them the leader position. Despite a low land profitability of cereal farms, the labour factor is highly paid. This results from their area, the scale of production and efficient organisation of their own labour resources. A relatively low labour intensity of monoculture crop production allows not to hire paid workers.

\section{Summary}

This article focuses on the issues of productivity and profitability of commercial agriculture. Particular attention was paid to the forms of sustainable agriculture - the farms that provide services for the natural environment, namely: organic, agri-environmental, norfolk and sustainable farms. Cereal farms - which have highly specialised crop production - were chosen as the opposite group. The studies have been conducted on the basis of the results of agricultural accounting collected under FADN for 2012.

The conducted studies showed that the identified forms of sustainable agriculture are differentiated by the production potential, which is expressed as the volume of involved factors of production - land, labour and capital. The production potential of most examined forms of sustainable agriculture can be considered comparable to the average FADN farms. Organic farms are an exception as their results are significantly lower than for the others, both in terms of numbers, area of agricultural land, livestock population, assets and the generated standard gross margin. On the other hand, the production potential of cereal farms is similar to the average, although their arable land is two times larger. This result is a proof of the importance of animal production and diverse crop production for the value of the standard gross margin. Multifunctionality of agricultural production and diversified crop structure contributes not only to the assurance of environmental benefits, but also tangible economic benefits.

The selected forms of sustainable agriculture do not match the other farms in terms of the generated production volume. In the long term and with a full economic account including the externalities, these relations would probably be opposite in favour of sustainable forms of farming. Farms with a simplified crop structure, with intensive production and the ones that exploit the natural resources do not generate impressive production results, and what is more, they are far from the average.

In terms of labour productivity, some forms of sustainable agriculture keep up with the average ones. On the other hand, cereal farms featured the highest labour productivity, which was dictated by a relatively low labour intensity, which is a result of both a simplified crop production, departure from absorbing livestock production and an efficient use of their own labour resources. Further economic and production categories related to land area indicate that the differences are disappearing between the forms of sustainable agriculture and cereal farms and the average entities. The vanishing distance between them resulted from a more favourable level of costs and from the balance of current subsidies and taxes.

The presented values for land profitability of the analysed groups indicated that agrienvironmental, norfolk and sustainable farms had profitability similar to that of the average FADN farm, while organic farms could not match them. A slightly different picture emerges 
when analysing labour profitability because a result comparable to the average was achieved by norfolk farms, but a better one was featured by agri-environmental and sustainable farms, which should be considered a promising rationale for the further development of such farming forms. Unfortunately, also in this regard, organic farms generate worse economic effects. On the basis of the relatively unfavourable economic results of organic farms, it can be concluded that the financial support under governmental programmes targeting such a system of farming is inadequate.

Despite low land profitability of cereal farms, the own labour rate achieves an impressive level. This is primarily a result of a large area and a relatively low labour intensity.

\section{References:}

Bocian M., Malanowska B. (2014). Wyniki Standardowe 2012 uzyskane przez indywidualne gospodarstwa rolne uczestniczące w Polskim FADN. Część I. Wyniki Standardowe. Warszawa: IERiGŻ-PIB.

Byerlee D., Murgai R. (2001). Sense and sustainability revisited: the limits of total factor productivity measures of sustainable agricultural systems. Agricultural Economics, 26(3) 2001: 227-236.

Gollop F., Swinand G. P. (1998). From Total Factor Productivity to Total Resource Productivity: An Application to Agriculture. American Journal of Agricultural Economics, 80: 577-583.

Goraj L. (2009). Rachunkowość i analiza ekonomiczna w indywidualnym gospodarstwie rolnym. Warszawa: Difin.

Goraj L., Bocian M., Cholewa I., Nachtman G., Tarasiuk R. (2012). Współczynniki Standardowej Produkcji „2007” dla celów Wspólnotowej Typologii Gospodarstw Rolnych. Warszawa: IERiGŻ-PIB.

http://www.minrol.gov.pl

Melfou K., Theocharopoulos A., Papanagiotou E. (2007). Total Factor Productivity and Sustainable Agricultural Development. Economics and Rural Development, 3(1): 32-38.

Nachtman G. (2014). Wyniki Standardowe 2012 uzyskane przez ekologiczne gospodarstwa rolne uczestniczące w Polskim FADN Część I. Wyniki Standardowe. Warszawa: IERiGŻ-PIB.

Prandecki K., Wrzaszcz W., Buks J., Bocian M. (2014). Z badań nad rolnictwem społecznie zrównoważonym [25] Produktywność wybranych form rolnictwa zrównoważonego. K. Prandecki (ed.). Warszawa: IERiGŻ-PIB.

Rapidel B., DeClerck F., Le Coq J-F., Beer J. (eds.) (2011). Ecosystem Services from Agriculture and Agroforestry. Measurement and Payment. London, Washington DC: Earthscan.

Woś A., Zegar J. St. (2002). Rolnictwo społecznie zrównoważone, Warszawa: IERiGŻ.

Wrzaszcz W. (2014). Sustainability of Agricultural holdings in Poland. Studia i monografie, No. 161, Warszawa: IERiGŻ-PIB.

Wrzaszcz W., Zegar J. S. (2014). Sprawność ekonomiczna wybranych form rolnictwa zrównoważonego środowiskowo In: Z badań nad rolnictwem społecznie zrównoważonym [23]. J. St. Zegar (ed.). Warszawa: IERiGŻ-PIB. 